\title{
THE ALLURE OF LEGALIZATION RECONSIDERED: THE CASE OF SPECIAL EDUCATION*
}

\author{
David Neal $\dagger$ \\ AND \\ DAVID L. KIRP**
}

\section{SUMMARY}

Legalization has been called a major trend in American public life. Yet it is a phenomenon that is conceptually unclear and little understood in the way it affects the institutions on which it comes to operate.

This paper concerns special education, the subject of the Education for All Handicapped Children Act (EAHCA), ${ }^{1}$ which was passed in 1975. It will proceed in three steps. Initially, the legislation and the process leading to its passage and implementation will be examined as a case study in legalization. Next, the concept of legalization and its motivations will be outlined and ana-

Copyright (C) 1985 by Law and Contemporary Problems

* Jack Tweedie, our co-researcher in a broader study of special education policy, made invaluable contributions to this paper. Richard Abel, Jack Goldring, Sheldon Messinger, Philip Selznick, Martin Shapiro, and Julius Stone read and commented on earlier drafts of the paper.

A major portion of this research is based on interviews with the principal congressional staff people and lobbyists involved in the passage of the Education for All Handicapped Children Act of 1975 (EAHCA). Interviews were conducted in Washington in July and August 1980, and tape recorded. Interviewees agreed to the interview on the basis that their views were not for attribution. Hence where a quotation appears in the text, only the most general reference to the source is given. It should be appreciated that these people were reporting events that had occurred up to eleven years prior to the interview. Some interviewees referred to documents and memoranda, although most did not. We sought to ensure accuracy by cross-checking one report against another where possible and against whatever records were available. By exercising what we trust was a healthy skepticism, we hope to have minimized inaccuracy. Nevertheless, most of the people we interviewed still work closely with and have discussed the events among one another. There is a need then, to remain cautious about the data. Finally, we submitted a copy of our draft to two of the principal policymakers for comments and suggested revisions. This methodology has yielded a richer account of the policymaking process leading to the EAHCA than reliance on the records could have done. We want to thank the following persons and organizations who generously made large amounts of their time available to us: Michael Francis, Staff Member for Senator Robert Stafford; James Galloway, National Association of State Directors of Special Education; Thomas Gilhool, Attorney for Pennsylvania Association for Retarded Citizens; Robert Herman, Bureau of Educationally Handicapped; Ronald Howard, National Association of State Boards of Education; John Martin, Council of Chief State Schools Officers; Roy Millenson, Staff Member for Senator Jacob Javits; John Morris, Department of Education; Marilyn Roth, American Federation of Teachers; Gus Steinhilber, National School Boards Association; Lisa Walker, Staff Member for Senator Harrison Williams; Fred Weintraub, Council for Exceptional Children; James Wilson, Pennsylvania Association for Retarded Citizens; Daniel Yohalem, Children's Defense Fund.

$\dagger$ Lecturer, Faculty of Law, University of New South Wales, Australia.

** Professor, Graduate School of Public Policy, and Lecturer, School of Law, University of California at Berkeley.

1. Pub. L. No. 94-142, 89 Stat. 773 (codified as amended at 20 U.S.C. $\S \S 1400-1461$ (1982)). 
lyzed with respect to how legalization shaped special education policy. Finally, the article will discuss the effects of legalization on the institutions into which it is introduced. Within this context, the article will look at both the use of the due process procedures and the wider setting of legalization in the education sphere.

\section{INTRODUCTION}

American public policy has recently witnessed the legalization of a host of issues previously left to political or professional solution. ${ }^{2}$ The declaration of substantive rights coupled with reliance on law-like procedures has become a characteristic way of framing policy. While legalization has been studied in a number of contexts-industry, ${ }^{3}$ regulation, ${ }^{4}$ education, ${ }^{5}$ and race relations ${ }^{6}$ there is no precise understanding of how legalization comes to dominate policy or its effect upon implementation. ${ }^{7}$

This article will try to improve understanding of these issues by focusing on special education policy. Special education is an ideal case from which to mount a study of legalization. From the first articulated claims, to recognition that handicapped children have a right to education, to the development of special education, policy at the federal level and the implementation of that policy in schools, the evolution of legalization can be traced and its appropriateness analyzed.

The ramifications of this case study go beyond special education and raise general questions about legalization. At the time special education was being legalized, researchers were beginning to express reservations about legalization. Studies of delegalization, alternative forms of dispute resolution, and the nature of disputing counselled a greater sensitivity to legalization's limitations and pathologies. ${ }^{8}$ Special education demands particular attention because, unlike the other examples referred to, its legalization has been imposed on schools, which have previously relied on other bases for decision-

2. For a discussion of these policy frameworks, see Kirp, Professionalization as a Policy Choice: British Special Education in Comparative Perspective, 34 World Politics 137 (1982).

3. P. Selznick, Law, Society, and Industrial Justice (1969).

4. R. Kagan, Regulatory Justice (1978).

5. Kirp, Proceduralism and Bureaucracy: Due Process in the School Setting, 28 Stan. L. Rev. 841 (1976).

6. L. Mayhew, Law and Equal Opportunity (1968).

7. See Abel, Delegalization: A Critical Review of Its Ideology, Manifestations and Social Consequences, in Alternative Rechtsformen und Alternativen zum Recht: Jahrbuch fur Rechtssoziologie und Rechtstheorie, band 6.29 (E. Blankenburg, E. Klausa, and H. Rottleuthneer eds. 1980) [hereinafter cited as Alternatives].

8. The clearest statement about limitations came from the seminal article by Galanter, Why the "Haves" Come Out Ahead: Speculations on the Limits of Legal Change, 9 LAw \& Soc'y Rev. 95 (1974). He has also written insightfully on delegalization in Legality and Its Discontents: A Preliminary Assessment of Current Theories of Legalization and Delegalization, in ALTERNATIVEs, supra note 7, at 11 and on the background effect of formal adjudication on dispute resolution in Justice in Many Rooms, $19 \mathrm{~J}$. LEGAL PLURalism 1 (1981). See also, e.g., Abel, supra note 7; R. Abel, The Politics of Informal Justice (1982); The Disputing Process in Ten Societies (Nader \& Todd eds. 1972). On the nature of disputes, see Fitzgerald and Dickins, Disputing in Legal and Nonlegal Contexts: Some Questions for Sociologists of Law, 15 LAW \& Soc'y REv. 681 (1980). 
making. ${ }^{9}$ Before addressing these concerns, however, a more complete treatment of the process of legalization is in order.

\section{II}

\section{LEGALIZATION}

Legalization is only one way to give substance to a policy objective, ${ }^{10}$ and one which, at least in its fully developed form under the EAHCA, is fairly new to policymaking in the United States. It is nonetheless a style close to the mainstream of American social and political culture.

The characteristic features of legalization include a focus on the individual as the bearer of rights, the use of legal concepts and modes of reasoning, and the employment of legal techniques such as written agreements and court-like procedures to enforce and protect rights. The EAHCA is filled with legal concepts and procedures: the notion of right or entitlement, the quasi-contractual individualized education program (IEP) meeting in which the right is elaborated, the provision of due process guarantees and appeal procedures, and implicitly, the development of principles through the mechanism of precedent.

A preference for legalization is premised on the classically liberal belief that individuals, and not the organization charged with delivering a good or service, can best safeguard their own interests. Paradoxically, the very fact that the individual has not been an effective self-guardian is the rationale for offering him or her the resources of the state, thus empowering the individual to pursue this interest. Individuals cannot attain the policy goal unaided, either because of ill will on the part of the service provider, or because of an absence of consensus between the individuals and the service deliverer with respect to the goal to be achieved.

Legalization betokens a mistrust of other forms of accountability, particularly accountability based on bureaucratic norms of fairness using statistical tests across classes of affected people. It defines accountability in individual terms; that is, a person polices his or her own interests. Individual accountability also implies singling out a party responsible for malfeasance in a way that group compliance procedures do not.

The aspirations underlying legalization include a desire for principled decisionmaking, minimization of arbitrariness, and a concern for the rights of the individual. In an extreme case, where an organization is frozen into traditional methods, legalization may be needed to bring about a reorientation of goals and priorities. This may entail changes in the power relations between

9. By contrast Kagan, Mayhew, and Selznick focus on the spontaneous appearance of legalization as a response to an organization's own perceived needs. See R. KaGan, supra note 4; L. MAYHEW, supra note 6; P. SELZNICK, supra note 3.

10. In a sense, any time Congress makes a law one can say the policy area has been "legalized." That is not the sense we intend to convey here. Rather, we attempt to identify and characterize a particular method or style of policymaking and distinguish it from other ways of achieving policy objectives. 
clients and service providers and, as in the case of special education, may involve rearrangement of status positions within the hierarchy of the delivery agency. At the same time, the dangers of the approach should not be minimized. One danger is that professionals in key positions may be alienated. More generally, legalization may degenerate into legalism: a narrow approach in which law and procedures become ends in themselves and substantive goals are lost in mechanical adherence to form. ${ }^{11}$

The distinctive features of legalization become clearer if one compares this apprach to other modes of government policymaking. Under a professional model, experts administer and enforce a policy mandate. The beneficiary occupies a passive role, deferring to the professionals' expertise. This model is widely prevalent: it is exemplified in the Federal Vocational Education Program $^{12}$ and, outside the education field, in the Legal Services Program. ${ }^{13}$ This type of service provision leaves little or no room for the recipient to define the nature and extent of the benefit. Instead, the benefit is defined in the legislation itself or by professionals administering the program. Nor does the recipient play any significant role in maintaining accountability in the system; that function is carried out bureaucratically, through agency review focusing on regularity of systems and procedures. Such agency review relies on policy which impacts on classes of people using probabilistic statistical testing, rather than on a case-by-case review. Indeed, the very notion of an individual right is foreign to this approach.

Compared to the legalization model, the professional model places much more responsibility on the experts' exercise of discretion. Results rather than principles, discretion rather than rules, and groups rather than individuals are emphasized. The individual has little say about the nature or extent of the benefit and the narrower avenues of redress. This is in marked contrast to a legalized model, particularly one using contractual forms treating the individual as a definer and enforcer of the right in question.

Programs providing money payments-welfare, social security and the like - constitute a second variant of government policymaking. These bureaucratic models give less discretion to program administrators than the professional model. Legislation specifies the type of benefit and eligibility criteria and the program is administered by a government department. The notion of

11. Selznick described the problem of legalism in this way:

But legal correctness has its own costs. Like any other technology, it is vulnerable to the divorce of means and ends. When this occurs, legality degenerates into legalism. Substantive justice is undone when there is too great a commitment to upholding the autonomy and integrity of the legal process.

P. SelzNick, supra note 3, at 13. Distinguish this usage of legalism from that of Judith Shklar who means something synonymous with the rule of law. J. SHKLAR, Legalism 12 (1964).

12. We are indebted to Martin Shapiro for this example. For a history of federal vocational education policy see C. Benson, Centralization and Legalization in Vocational Education: Limits and Possibilities, in School Days, Rule Days: The legalization and Regulation of Education (D. Kirp ed. 1984) [hereinafter cited as D. KIRP].

13. See J. Handler, E. Hollingworth \& H. Erlanger, Lawyers and the Pursuit of legal. Rights 29-39 (1978). 
an individual right has more relevance in this model than in the professional model because greater emphasis is placed on safeguards built into the legislative apparatus. The right, however, is a very limited one in comparison to the legalization model. Unless the claimant can show that the exercise of administrative discretion was either "outrageous or stupid," 14 the best that can be hoped for is that the court will ask the agency to review the matter. By contrast, in the legalized model for special education, a due process hearing passing on a contract-like document, the IEP, is not limited to a review of administrative discretion; the individual may rely on a written agreement to provide substance for a ruling on the merits of the case. The existence of a written IEP, possibly some sort of record of the negotiations, and the opportunity to have input on the substance of the right gives the claimant much more scope for enforcing that right than the narrow bureaucratic model. ${ }^{15}$

The history of the handicapped reveals that choice among styles of policy implementation-legal, professional and bureaucratic-affects the services that are provided. The choice determines the type of service offered, who receives it, and on what terms. It limits the degree of variation and affects the stakes the client group has in the service. It also fixes the extent of regulatory control and the means of redress available to the client group. ${ }^{16}$

III

\section{Evolution of a Right}

Two million handicapped children between 7 and 17 years of age were not enrolled in school in 1970.17 Many were excluded by state laws, like the Pennsylvania statutes attacked in the $P A R C$ case, ${ }^{18}$ which designated them as ineducable or untrainable. Other handicapped children were consigned to institutions offering only custodial care. By the late 1960's, the wretchedness of the treatment meted out to the handicapped at institutions such as Willowbrook and Pennhurst ${ }^{19}$ and the specious nature of the rationale for excluding handicapped children from schools ${ }^{20}$ led reformers to demand a radical change in the way handicapped people generally, and handicapped children in particular, were treated. The means adopted for effecting this change were

14. On this and other problems of welfare beneficiaries in suing government officials, see Handler, Controlling Official Behaviour in Welfare Administration, in The LAW OF THE PoOR 155, 160-61, 170 . 76 (J. ten Broeck ed. 1966).

15. Id.

16. Kirp, supra note 2 , at $138-39$.

17. Children's Defense Fund, Children Out of School (1974). Other sources state that there were some 7 million handicapped children of whom only 40 percent were receiving an adequate education. See, e.g., H.R. Rep. No. 805, 93d Cong., 2d Sess . 53, reprinted in 1974 U.S. Code Cong. \& AD. News 4093, 4138.

18. Pennsylvania Ass'n for Retarded Children v. Pennsylvania, 343 F. Supp. 279 (E.D. Pa. 1972).

19. The Pennhurst State School and Hospital, the object of the PARC litigation, enjoyed some notoriety for overcrowding, lack of staff, and inadequate treatment. One commentator described it as "a Dachau without ovens." L. Lippman \& I. Goldberg, The Right to Education 17 (1973).

20. The evidence of the experts brought to testify in the $P A R C$ case on the educability of the handicapped was so overwhelming that after one day of testimony the defendants conceded that all children could benefit from education. Id. at 29. 
distinctively legal. The language of rights and the mechanisms of due process were introduced into an area that had previously relied on the professional discretion of teachers, psychologists, and school administrators. ${ }^{21}$

\section{A. From Proclamations to Courts}

The civil rights movement and the War on Poverty provided the key ideas and context for the movement on behalf of handicapped people. Both movements heavily emphasized legal rights and focused the idealism of a generation of policymakers whose interests brought them in contact with powerless groups. The emphasis on rights and the active participation of those previously regarded as dependents in decisions affecting their lives, as well as more direct analogies from the emphasis on due process in the student rights movement, ${ }^{22}$ suggested strategies to activists in the area of special education. The position of the retarded could be and was analogized to that of blacks, Native Americans, and the poor. For many of these groups the courts were the only effective point of entry into the political system. The courts gave power to groups which otherwise had none, groups which could not attract the attention of legislatures at the state or federal level.

The way in which a claim is defined, and the orchestration of the campaign to have it ratified, are crucial in determining whether it will be recognized at all, and, if recognized, the level of such recognition. The transformation of the political perception about the claims of the handicapped from charity to right began in the 1950's. The formation of associations for retarded citizens at national and state levels was a significant step. The most influential of these organizations was the National Association for Retarded Children. ${ }^{23}$ Key figures in this movement carried out research establishing the educability of all children and publicized their findings through an extended national network. The associations became active not only on the political level, but also as service deliverers. For example, the Pennsylvania Association for Retarded Children (PARC) developed and ran state agency-funded programs for handicapped children.

Two crucial research findings became widely accepted in the education community. The first, that all children could benefit from education ${ }^{24}$ undermined the rationale that retarded children should be excluded from public schools because they were ineducable. Research also suggested that testing procedures for the assignment of children to classes for the retarded were racially discriminatory, ${ }^{25}$ thus strengthening the analogy between the retarded

21. On the use of rights as a political resource, see S. Scheingold, The Politics of Rights: Lawyers, Public Policy and Political Change 8-9 (1974).

22. See Goss v. Lopez, 419 U.S. 565, 576 n.8 (1975). See generally Kirp, supra note 5.

23. L. Lippman \& I. Goldberg, supra note 19, at 10.

24. Id. at 29.

25. Id. at 8-9. See also Larry P. v. Riles, 343 F. Supp. 1306 (N.D. Cal. 1972), affd, 502 F.2d 963 (9th Cir. 1974) (The court found that, while blacks formed 28.5 percent of the school district's population, black children comprised 66 percent of classes for educable mentally retarded as a result of IQ testing. The court enjoined the use of the then current IQ test as racially discriminatory.); Hobsen v. Hansen, 269 F. Supp. 401 (D.D.C. 1967). 
and racial minorities. The issue of educating handicapped children had undoubted appeal. Once it became arguable that such children were capable of being educated, it became virtually impossible to mount a politically palatable argument denying handicapped children's claim to education. While educating handicapped youngsters might be expensive, how could costs be weighed against reclaimed lives?

The handicapped rights movement had gained considerable momentum by the late 1960's. While organizations representing the interests of the handicapped had been formed, they had been able to extract only expressions of good intent from the states. One such group, PARC, decided that court action was the only means to break the impasse. The initial focus of PARC's attention was the Pennhurst State School and Hospital, the subject of considerable press and political attention for inhumane treatment of its patients. ${ }^{26}$ PARC had engaged in a long battle with Pennsylvania authorities about the conditions at Pennhurst, but to little avail, and so turned to legal counsel. The influence of legal modes of thought in framing and defining the issues, even at this early stage, is noteworthy. PARC's attorney, Thomas Gilhool, advised that the most promising strategy for attacking the Pennhurst situation was to insist on handicapped youngsters' legal right to education.

The case that Gilhool mounted was formidable. He was able to assemble a group of witnesses with overwhelming expertise in the field of special education $^{27}$ and to forge a link with the Council for Exceptional Children (CEC), a group which had already demonstrated its effectiveness at the state level and which was to become the major federal lobbyist for handicapped children. ${ }^{28}$ The plaintiff's monopoly of expertise and weight of evidence swamped the defense. After one day of testimony the Commonwealth withdrew its opposition to the complaint. ${ }^{29}$

The final court order, which was handed down in May $1972,{ }^{30}$ enjoined the defendants from applying statutes excluding mentally retarded children from public education. It required them "to provide every retarded child access to a free public program of education and training appropriate to his or her learning capacities." 31

The order also included a detailed stipulation to the procedures that had to be followed in classifying mentally retarded children. It specified a full range of due process procedures, including: parents' or guardians' right to written notice of changes in educational status; the opportunity for a due pro-

26. L. Lippman \& I. Goldberg, supra, note 19, at 16-17.

27. For a list, see id. at $28-29$.

28. The CEC is a national professional organization with 90 percent of its membership composed of special education teachers. Unlike teacher unions, it has no responsibility to its membership for wages and employment conditions. Its purpose is to develop policy in the field of special education. This policy is formulated very broadly by a national convention which enunciated a statement of handicapped children's rights in 1969 along with drafting a model statute for state legislatures.

29. L. Lippman \& I. Goldberg, supra note 19, at 29.

30. Pennsylvania Ass'n for Retarded Children v. Pennsylvania, 343 F. Supp. 279 (E.D. Pa. 1972).

31. Id. at 302 . 
cess hearing where the parents may be represented by counsel, may call and cross-examine witnesses, and may examine records relating to the child; and the right to a verbatim record of the proceedings.

The consent agreement in PARC was the culmination of the first stage of the legalization of special education. Political pronouncements about the rights of the retarded were translated into legal arguments and formally recognized in a court of law as protected by the United States Constitution. The federal district court judgment in Mills, ${ }^{32}$ issued the following August, reiterated the rights established in $P A R C$ and extended them to all handicapped children. There was more to come. PARC and Mills precipitated a rash of litigation across the country, both inspired and orchestrated by lobby groups on behalf of the handicapped in order to pressure state governments into action. Some thirty-six cases were filed in twenty-one jurisdictions. ${ }^{33}$

The commitment of a policy area to the hands of attorneys has significant policy ramifications. Rights take on a life of their own in the hands of lawyers, who bring a particular conceptual framework to the problems with which they deal. Analogizing the claims of the retarded to the legally cognizable right to education preempts other potential ways of framing the issues. To cast a claim in terms of a Fourteenth Amendment right also implies creating a set of procedures to protect the right. In the consent agreement drawn up between the lawyers for the parties in $P A R C$, which was relied upon in subsequent cases, a detailed set of due process procedures figures prominently. Similar provisions were incorporated in the model statute drafted by CEC. Using the threat of litigation as leverage, organizations such as CEC lobbied successfully for new state legislation. By 1974, twenty-five states required due process procedures. ${ }^{34}$

\section{B. From Test Case to Federal Legislation}

Publicity about the treatment of the handicapped led to the introduction of bills adding the handicapped to Title VI of the Civil Rights Act. ${ }^{35}$ Discrimination against the handicapped in education was specifically mentioned as one reason for the proposed amendment. ${ }^{36}$ The emergence of these issues prompted formation of the Senate Sub-Committee on the Handicapped early in 197.2. These developments spurred lobby groups for the handicapped to respond and groups which had traditionally focused their efforts at state and local level were drawn into the Washington orbit.

32. Mills v. Board of Educ., 348 F. Supp. 866 (D.D.C. 1972).

33. R. Martin, Educating Handicapped Children: The Legal Mandate 15 (1979).

34. Abeson, Bolick \& Hass, Due Process of Law: Background and Intent, in Public Policy AND THE Education of Exceptional Children 30 (1976).

35. The House Bill was introduced by Congressman Charles Vanik of Ohio on December 9 , 1971. 117 Conc. REC. 45,974-75. Senator Hubert Humphrey introduced a similar bill into the Senate on January 20, 1972. 118 Cong. REc. 106-07. These bills later became $\$ 504$ of the Rehabilitation Act of 1973, Pub. L. No. 93-112, 87 Stat. 355 (1973) (currently codified at 29 U.S.C. $§ 794$ (1976)).

36. R. MARTIN, supra note 33 , at $16-17$. 
Issues involving the handicapped were tentatively placed on the federal agenda. The court cases, however, proved to be the decisive factor because they created a more expensive standard for the school systems to meet. This financial pressure forced the states to turn to Washington for assistance and convinced policymakers in Washington of the need for federal initiatives.

The court opinions also led lobby groups for the handicapped to focus on Washington. The CEC, which had played an influential role in orchestrating the litigation and using it to force states to enact special education legislation, had doubts about the constitutional firmness of the court decisions because none of the cases had been appealed. A federal statute would establish an authoritative national standard which would not have resulted if some of the other cases were lost. While maintaining pressure by continuing to bring suits, the primary focus of the lobby groups for the handicapped changed from seeking substantive change at state level to forcing states to accepteven to promote-federal legislation. The strategy dictated that states be obliged to accept conditions to be imposed by new federal legislation in order to obtain the funds necessary to comply with court orders.

The courts were thus a crucial factor in the combination of events which put special education on the federal agenda. The influence of the courts, however, went beyond this by shaping the substance of policy at the federal level.

\section{The Individualized Education Program (IEP)}

The courts approached special education by determining whether handicapped children possessed a right to education. Since courts often deal with individuals as bearers of rights, this format made special education legally cognizable because one's right to it could be protected by due process procedures.

This emphasis on individual needs suited the professional concerns of the CEC as well as the procedural biases of the legalized model. That congruence in turn predisposed policymakers to deal with further policy questions in a legalized mode. Individualism was also critical to the next step in the process of legalization.

The courts had declared the right of handicapped children to a free and appropriate public education, with a presumption that a student be placed in the least restrictive school environment (the environment as similar to the regular classroom as possible). Beyond that, though, the substance of the right was unspecified. Once the idea of an individual right to an appropriate education was accepted, it became nearly impossible to define the substance of the right to education in general terms, for the needs of individuals varied so greatly. Moreover, even if a categorical definition could have been produced, it would have been politically difficult. Since education was still regarded as essentially a local responsibility, even in this interventionist era, federal substantive mandates seemed excessive.

The device settled on to elaborate the right to education, as it appeared in 
the first Senate bill, was the IEP: " a written educational plan for a child developed and agreed upon jointly by the local educational agency, the parents or guardians of the child and the child when appropriate . . . ."37 The program was to contain a statement of the child's level of educational performance, long-range educational goals, intermediate objectives, the specific services to be provided, the date of commencement and the duration of the services, and objective criteria and evaluation procedures to determine whether the goals were being achieved. ${ }^{38}$

The character of the IEP process is legal and not administrative. Rather than empowering an administrator to exercise discretion in delivering preordained services to a recipient, the Act recognizes that the handicapped child has a right. This right entitles the child or the parents to negotiate as parties with school officials and involves them in the task of defining the nature and extent of the services to be delivered. This quasi-contractual process is a logical extension of the right to education already established by that stage of the policymaking process. ${ }^{39}$

The IEP is also an ingenious device in terms of political acceptability. It avoids attempting to mandate specific services; it recognizes the rights of recipients, empowers them, and involves them in the process. It avoids encroaching on the professional discretion of teachers and potentially enhances their influence over placement decisions. It provides a means of holding local administrators accountable while paying some deference to the belief that the federal government should not interfere too much with local autonomy in education. Finally, it appeals to local school officials by fixing the upper limit of the liabilities with respect to each child. ${ }^{40}$

\section{Compliance: Legalization Begets More Legalization}

For the IEP to be a meaningful contract, a means of enforcing its provisions and of assuring compliance with the aims of the law had to be found. A way for parents to express dissatisfaction with the IEP procedure or the performance of local officials was therefore required, as was an assurance that

37. S. 6, 93d Cong., lst Sess. $\$ 3(9)$ (1973). (The teacher's participation in development of the IEP was added in 1975. S. 6, 94th Cong., 1st Sess. (1975)).

38. Id.

39. The term quasi-contractual is used advisedly. The National School Boards Association was at pains to ensure that the IEP not be seen as a contract from which specific performance and other court remedies would flow. CEC agreed to this. House Select Education Subcommittee Hearings, 10 April, 1975, 76. The Senate Labor and Education Committee expressed a similar concern. S. REP. No. 168, 94th Cong., lst Sess. 11, reprinted in 1975 U.S. Code Cong. \& Ad. News 1425, 1435. One of the first expressions of the idea of a contract was in Gallagher, The Special Education Contract for Mildly Handicapped Children, 38 Exceptional Children 527 (1972). As one of the policymakers we interviewed summed it up:

We intended to strengthen the hands of parents . . . . It was a way of individualizing and contractualizing the relationships and involving parents in the process. . . It's a way of enforcing

what should be delivered to kids. While it's said not to be a contract, it is a contract for service. Note the commitment to the involvement and empowerment of the recipient. The interviewee alluded to the 1960's and the War on Poverty explicitly later in the interview.

40. One of our respondents informed us that this last item was a selling point for the IEP to local boards. 
federal funds were being spent in accordance with the objectives of the legislation.

Early legislative drafts emphasized agency review, a bureaucratic mode of accountability. As the legislation took final form, however, due process guarantees and not administrative monitoring became the primary compliance mechanism. ${ }^{4}$ This outcome is a further extension of the legalization process, building on the established theme of individual entitlement and the quasicontractual IEP. Due process procedures, a natural concomitant of the legalized model, would not only serve as a means of redress for parents but also as a device for policing the expenditure of federal funds by local officials.

The history of this aspect of the legislation begins in the 1973 Senate bill ${ }^{42}$ with the monstrously impractical notion of forwarding all IEP's to the U.S. Commissioner of Education for review. The idea of detailed central oversight was abandoned when it was realized that the requirement entailed sending some eight million IEP's to Washington each year. The Senate's alternative was a state-level independent complaint agency called "the entity," 43 which would conduct periodic evaluations of State and local compliance, receive complaints from individuals, provide opportunity for hearings, notify the state or local agency of a violation and take steps to correct it. The House bill, by contrast, had developed a grievance procedure to be established by the local school district to receive complaints from the handicapped and carry out investigations. ${ }^{44}$

Neither bill entitled any individual to enforce his rights, thus creating a tension between the entitlement provisions of the IEP on the one hand and the enforcement provisions on the other. Advocacy groups, disenchanted with agency review procedures such as those employed by the Office of Civil Rights, put their opposition strongly: "We could have had a complaints, civil rights type procedure and done a study. We didn't want that. This was based on individuals, not group statistic things."

Conflict in the House-Senate conference committee over due process versus administrative review became acute when the decision was made to fund local school districts directly rather than give the states discretion to distribute the federal money. Administrative oversight could not assure accountability from some 16,000 school districts. Congressmen did not want to see "federal money being poured down the same old rat holes," as one policymaker put it, referring to the misuse of funds under earlier federal educa-

41. The first bill proposed in January 1973 contained a number of due process measures which looked almost identical to those contained in the PARC consent agreement. That bill did not, however, contain the full range of due process provisions ordered by the court in $P A R C$. From our interviews it seems that there was little discussion of the due process procedures until the conference committee stage, when there was heated debate due to the pressure to secure a compromise between the House and Senate bills. These bills contained agency review bodies, called "the entity" in the Senate bill, while the House bill included a set of "grievance procedures." These were at odds with one another and with the legalized concepts already implanted in the early drafts.

42. S. 6, 93d Cong., lst Sess. § 7(a) (1973).

43. Id. at $\$ 614(8)$.

44. H.R. 7217, 93d Cong., lst Sess. $§ 617$ (1973). 
tion legislation. Additionally, the advocacy and civil rights groups did not trust local school administrators and teachers and pushed for due process protections. The Children's Defense Fund (CDF) and the California Rural Legal Assistance Foundation (CRLA), both of which played a key role at this stage as advisors to the congressional conferees, were heavily involved in civil rights and poverty law litigation. Their experience in these fields produced a belief in rights, courts and court-like procedures, and a profound mistrust of bureaucratic accountability.

Quite apart from the inconsistency of agency review with individual entitlement, political factors militated against agency examination. Any watchdog agency large enough to police 16,000 school districts would have resulted in too much violence to traditions of local governance in education. The due process provisions fit perfectly into the federal legislative scheme. They carried through the notion of individual entitlement developed in the IEP. They also enabled client and advocacy groups to undertake their own enforcement initiatives. Enlightened self-interest would obviate the need for a large watchdog agency and reassure advocacy groups like the CDF, which believed that courts and court-like procedures were the only way to counteract the power of local school boards. The due process provisions offered a means of resolving the deadlock between the House and the Senate over compliance mechanisms that were consistent with the legalized model. The conferees could embrace a solution that both embodied a logically coherent development of all that had gone before and solved their more pragmatic political problems. Although the states remained legally obliged to monitor local behavior, the due process procedures assumed primary importance as a means of ensuring compliance and providing a forum for individual grievances.

\section{IV}

The Appropriateness of the Legalized Model: The EMPIRICAL Evidence

\section{A. Introduction}

The evolutionary nature of legalization in special education policy precluded any detailed consideration of whether the legalized model was appropriate. Now that some of the major abuses that led to judicial and legislative intervention have been corrected, this question can be raised. ${ }^{45}$

This appraisal poses serious issues of policy. Does it make sense to impose a policy on education which places little faith in the professional discretion of the service provider? ${ }^{46}$ The implications of this shift are not lost on educators

45. Atkin, The Government in the Classroom, 109 Daedalus 85 (1980); Pittenger \& Kuriloff, Educating the Handicapped: Reforming a Radical Law, 66 Public InTErest 72 (Winter, 1982); C. Hassell, A Study of the Consequences of Excessive Legal Intervention on the Local Implementation of PL 94142 (1981) (Ph.D. Thesis, University of California, Berkeley \& San Francisco State University).

46. Of course professionals are coming under a great deal of fire in a number of fields. E. Goffman, Asylums (1961) (the medical profession); I. Illich, Tools for Conviviality (1973) 
who may resent the implicit loss of confidence. More generally, does legalization fit the needs and demands of schools or children? The imposition of legalization schemes onto ongoing complex organizations, such as schools, also creates particular problems. ${ }^{47}$ Studies of the implementation history speak less of the promise of legalization and more of its pathology. These studies reveal compliance with the letter rather than the spirit of the law: preparation of standard form IEP's, resentment over handicapped children gaining a priority that may get them more than their fair share of the education dollar, and defensive strategies, such as the tape recording of IEP meetings to protect the interests of the school district and teachers.

Yet the story is more complex than this. While implementation studies view the due process procedures as a separate and severable part of the federal legislation, these procedures are an integral part of a legislative scheme which adopts a legalized policy style. The appropriateness of this policy style must be judged with reference to the place of special education in the school system, not by ignoring this overall context and focusing only on the due process hearings. To be sure, the benefits to special education flowing from the federal presence, more money, more initiatives and the like, must be offset by the costs of the due process hearings. Yet the question is whether these gains could have been achieved without the legalized policy style of the EAHCA.

$A$ radical reorientation of priorities in special education was needed, and those who shaped the EAHCA determined that legalization was the only method to bring it about. In certain situations shock treatment is necessary to convince service deliverers in an ongoing institution that established patterns and values must be changed. Legalization was not the first but the last in a series of approaches taken by educators of the handicapped. Years of campaigning had not convinced the education community of the justice of the claims made on behalf of the handicapped.

Legalization was a plausible approach. Law may not be the only way to reorder priorities or legitimize claims; the availability of a great deal of new money for special education or the operation of a competitive market, for example, might have brought about the same result. But law and legal sanctions offered a surer and more direct means of institutionalizing the values promoted by the proponents of change. The embodiment of values in law and the possibility of sanctions offer powerful reference points to those implementing a reform, thereby serving as a rallying point for claims on the system and a powerful resource for responding to arguments from competing value positions. The law also provides a framework within which values can be translated into services and new values and services can emerge, for it requires the adjustment of power positions of the various groups within a

(professions generally); Wasserstrom, Lawyers as Professionals: Some Moral Issues, 5 Human Rights 1 (1975) (the legal profession).

47. L. MAYHEW, supra note 6 , at 1-30, 258-84 (especially at 23). On implementation in special education see R. Weatherley, Reforming Special Education: Policy Implementation from State Level to STreet Level (1979) and on implementation generally, see E. Bardach, The ImplementaTION GAME (1977). 
system. Proponents of the new values gain power in the institution and can introduce further changes on behalf of their interests.

In short, legalization is neither so cost-free as its proponents suggest nor so defective as subsequent analyses contend. In what follows, this article will explore the effects of legalization by examining the implementation of the EAHCA with particular emphasis on its due process mechanisms.

\section{B. Implementation: The Due Process Procedures}

Studies of the implementation of the due process aspects of the EAHCA are the best available indicators of the effects of legalization, but they need to be evaluated with caution. ${ }^{48}$ These studies report a fairly short experience of the legislation and necessarily do not deal with the possibility that implementation improves over time.49 They are also flawed in a variety of ways. For example, the research typically relies on small, non-random samples of individuals involved in the hearings. While valid as a guide to the experience of those who undertake a hearing, these cases focus on the deficiencies of the process. They do not speak to the appropriateness of the due process procedures generally, nor to the general level of satisfaction with the Act experienced by parents of handicapped children. This research approach shortchanges the systemic effect of the procedural reforms. Moreover, since the studies only report the post-legislation experience, the ill effects attributed to the due process procedures may simply be old problems transferred from other forums or made more visible by the existence of the hearings.

1. The IEP Meeting. The notification and procedural requirements necessary to draw up the IEP and hold the meeting are generally in place. ${ }^{50}$ Despite some early hearings in which schools failed to comply with notice deadlines and the like, the mechanics of the IEP procedure seem to be operating.

The qualitative picture is not as clear. Two types of IEP meetings have been identified: a legalistic form in which half the time is devoted to narrow procedural requirements, and a child-oriented form, faithful to the spirit of the law. ${ }^{51}$ IEP sessions in which the parents are overwhelmed with professional jargon and other strategies used by schools to minimize the portion of

48. They are: M. Budoff \& A. Orenstein, Special Education Appeals Hearings: Their Form, and the Response of Participants (1979); R. Weatherley, supra note 47; Benveniste, Implementation and Intervention Strategies: The Case of P.L. 94-142, in D. KIRP, supra note 12; Hassell, supra note 45; Kirst \& Bertken, Due Process Hearings in Special Education: Some Early Findings from Califormia, in SPECIAL Education Policies 136 (Chambers \& Hartman eds. 1983); Stearns, Green \& David, Local Implementation of P.L. 94-142 (1979) (Discussion Draft: SRI International). The studies by Weatherley and Budoff and Orenstein are of the equivalent Massachusetts legislation, the Comprehensive Special Education Law of 1972. 1972 Mass. Acts 766 (codified as amended in scattered sections of Mass. Ann. Laws" chs. 69, 71 B (Law Co-op. 1978).

49. See Kirp \& Jensen, Law, Professionalism and Politics: The Administrative Appeals Procedure Under PARC v. Commonwealth of Pennsylvania, in D. KIRP, supra note 12.

50. Stearns, Green \& David, supra note 48 , at 81 .

51. Hassell, supra note 45 , at 52. 
their resources devoted to meetings have been reported in two states.52 There are also hearsay accounts of IEP's prepared in advance where the parent is pressured to sign on the dotted line, but there is little evidence to indicate how widespread this practice is.

Reactions to the IEP process are mixed. Parents generally seem satisfied, even enthusiastic, about the development of the IEP. However, in some districts, one-third of the parents describe the meetings as formalistic.53 Teachers generally regard the IEP as useful, but reports differ as to whether there is a high degree of actual use of the IEP as an instructional tool ${ }^{54}$ or whether instructional use is really the exception. ${ }^{55}$ Even this more pessimistic accounting acknowledges that the IEP has the force of law and serves as new found leverage both within the school and the district and provides a basis for a due process hearing. ${ }^{56}$

\section{Due Process Hearings.}

a. Number of hearings. The total number of due process hearings held pursuant to the EAHCA is not known. Scattered reports suggest wide variations from state to state. In California, 278 hearings were held in 1978-1979, the first year of uniform state regulations, and one-third of these were held in two school districts. That number represents just .08 percent of California's special education population. ${ }^{57}$ A nationwide study of twenty-two sites found that half had experienced hearings, of which seven had only one hearing. ${ }^{58}$ Massachusetts had 350 hearings between 1974 and $1977 .{ }^{59}$

As with litigation generally, it is difficult to determine whether those figures represent a large number of hearings compared to the number of people with grievances or whether hearings are highly unusual phenomena in relation to the number of people or even the number of complaints in a given area. ${ }^{60}$ Right to education hearings are not atypical in this regard.

The impact of hearings, however, cannot be measured simply in terms of the number of hearings held. ${ }^{61}$ The prospect of a hearing and estimations of its likely outcome shape the behavior of participants, both in the formulation of their basic relationships and in the way they handle their disputes. The "shadow of the law" 62 extends well beyond the formally affected parties.

52. Id. at 60; R. WeatherLy, supra note 47 .

53. Hassell, supra note 45 , at 113 .

54. Id. at 104 .

55. Stearns, Green \& David, supra note 48 , at 79-82.

56. Id.

57. Kirst \& Bertken, supra note 48 , at 141 .

58. Stearns, Green \& David, supra note 48 , at 98.

59. M. Budoff \& A. Orenstein, supra note 48, at 5-1.

60. See data cited in H. Ross, Settled Out of Court 5 (1970). The figures he uses were for 1963 and taken from K. Davis, Administrative Law: Cases - Text - Problems 5 (1965). See also Kirp, supra note 5, at 840 n.113; Nader, Disputing Without the Force of Law, 88 YALE L.J. 998, 1007 (1980).

61. H. Ross, supra note 60; R. WeAtherley, supra note 47; Galanter, Justice in Many Rooms, supra note 8; Mnookin \& Kornhauser, Bargaining in the Shadow of the Law: The Case of Divorce, 88 YALE L.J. 950 (1979)

62. The phrase is borrowed from Mnookin \& Kornhauser, supra note 61 . 
b. Who uses the hearings and for what end? Parents of upper and middle socio-economic status groups bring the majority of hearings. ${ }^{63}$ They are overrepresented while parents from lower income and minority backgrounds are underrepresented. ${ }^{64}$ This has prompted one commentator to observe that "[d]ue process and appeal procedures are used to advantage by the wellto-do and almost not at all by the poor." 65

The middle class are usually best able to press their claims. Factors similar to those identified in other contexts seem to be at work in relation to relevance of hearings in the special education context. People in ongoing relationships are unlikely to resort to legal sanctions. ${ }^{66}$ Parents who know that their children will have to deal with the local school district personnel for twelve years are understandably reluctant to resort to legal action, with all the anxieties that such undertakings generate, except in the most serious cases. The opportunities for reprisal even after an outcome favorable to the parents, and the difficulties of enforcing such a decision in the face of an intransigent school district, ${ }^{67}$ pose too great a risk.

Middle and upper class parents do not face such high odds, for they have an exit strategy. ${ }^{68}$ Their complaints typically assert the inability of the local school district to provide "appropriate" education and claim reimbursement for tuition in private schools. If this proves unsuccessful, these parents can pay for the private schooling themselves. Lower class parents do not have this option. When they are involved in hearings at all, it is most often to resist changes proposed by the school rather than to initiate change. ${ }^{69}$ The ongoing nature of their relationship with the school system means that circumspection is probably in the best interests of these parents. This pattern points up an important limitation on the capacity of due process to bring about change in professionally run bureaucracies. It also raises questions about the wisdom of placing primary reliance on due process to effect policy change.

c. Style of hearings. Adversariness and legalism seem to characterize the conduct of hearings. ${ }^{70}$ Rather than adopting an informal negotiating format, the due process hearings tend to provide a forum for culmination of long-

63. M. Budoff \& A. Orenstein, supra note 48, at 6-11 to -12; Kirst \& Bertken, supra note 48, at 153; Stearns, Green \& David, supra note 48, at 104. On private school placement see M. BuDoff \& A. Orenstein, supra note 48, at 6-11; Kirst \& Bertken, supra note 48, at 154-55; Stearns, Green \& David, supra note 48 , at 104 .

64. Kirst \& Bertken, supra note 48, at 151-54.

65. R. Weatherley, supra note 47, at 10. Kirst and Bertken report that where poor people do go to hearings they have a higher success rate. They suggest, however, that this may be due to the more limited nature of their claims and to the fact that they more frequently resist rather than propose changes. Kirst \& Bertken, supra note 48 , at 154.

66. See Galanter, Why the "Haves" Come Out Ahead, supra note 8; Handler, supra note 14; Macaulay, Non-Contractual Relations in Business: A Preliminary Study, 28 AM. Soc. Rev. 55 (1963).

67. Budoff reports a high degree of non-compliance by school districts with decisions unfavorable to them, and continuation of the conflict. M. Budoff \& A. Orenstein, supra note 48, at ch. 10.

68. A. Hirschman, Exit, Voice and Loyalty (1970).

69. See supra note 65.

70. M. Budoff \& A. Orenstein, supra note 48, at 9-1; Stearns, Green \& David, supra note 48, at 104 
term bad relations between the school and the parents. ${ }^{71}$ Lawyers aggravate the situation, rendering proceedings more legalistic. ${ }^{72}$ Emphasis on compliance with procedural matters, such as notices, signatures, and time deadlines, offers an easy substitute for harder substantive questions, such as the meaning to be given to the word "appropriate" in the phrase "free appropriate public education." This legalistic pattern seemed particularly evident in the earlier stages of implementation. As schools learned to comply. with the forms of the law, opportunities for evasion diminished, and there was some evidence of reduced formalism. This evidence included reliance on "pre-hearing hearings" and negotiations among the participants. ${ }^{73}$

Parents generally reported considerable financial and psychological costs to the hearing process. They often felt themselves blamed either for being bad parents or for being troublemakers. Many perceived the school district officials to be lying:

I've been through seizures and everything else with her, and this has been the worst affair of my life.

It's been hell. Absolute hell. I seldom speak about it, even to my husband because I find that it gets me extremely upset. . . .

My hands right now are shaking as I am talking to you about it. I'm cold and I get that same horrible feeling all over . . . . [b]ut I feel that it is very difficult to go in and sit across from someone 2 or 3 feet away and have them lie blatantly and not be able to say anything about it. ${ }^{74}$

School districts regarded the hearings as expensive, time consuming, and a threat to their professional judgment and skill. The private school placements which parents often sought are enormously costly and also carry an implied criticism of the public school program. Directors of special education programs often regarded parents seeking these placements as "ripping off" the school system, depriving other children of the benefits that would otherwise accrue to the public school program. ${ }^{75}$ They complained about inconsistency in interpreting the appropriateness criterion from one hearing to the next and difficulties in accounting to the school board for expensive new services endorsed in hearings. ${ }^{76}$ Special education administrators see themselves as caught in a cross-fire between parents and school boards who blame them for failing to hold the line on expensive new services.

Some school districts which have experienced a number of hearings have developed an array of defensive strategies. There are reports of districts that stick to the letter of the law but protect themselves by tape-recording IEP meetings, retaining lawyers, tightening procedures, ${ }^{77}$ and interpreting educa-

71. M. Budoff \& A. Orenstein, supra note 48, at 9-1 to $-2,13-15,14-27$; Stearns, Green \& David, supra note 48 , at 101 .

72. M. Budoff \& A. Orenstein, supra note 48 , at 9-9.

73. Id. at 13-25; Stearns, Green \& David, supra note 48, at 104.

74. M. Budoff \& A. Orenstein, supra note 48, at 9-29.

75. Id. at 13-43; Stearns, Green \& David, supra note 48, at 108 . Kirst \& Bertken, supra note 48, at 163, warn of distortions in the allocation of public funds.

76. M. Budoff \& A. Orenstein, supra note 48 , at 13-24 to -25 .

77. Kirst \& Bertken, supra note 48 , at 159 . 
tion and related services narrowly. ${ }^{78}$ Other districts negotiated extra services with parents who promised not to pursue a hearing, or threatened to demand a hearing in order to coerce parents into accepting an IEP. ${ }^{79}$

While a few participants in due process hearings regarded them as positive experiences, allowing some sort of catharsis and a forum in which an independent party could suggest a solution, ${ }^{80}$ most held a negative view. In many instances, hearings have become an additional weapon with which the disputants can bludgeon one another. Parents see themselves as pursuing the best interests of their child, while the school district is anxious to preserve limited resources.

The negative effects of the due process hearings should not be exaggerated. Even though they impose a high economic and psychological cost on all involved, their incidence is concentrated in relatively few school districts. Furthermore, these are districts where parents have a long history of dissatisfaction with the school system. ${ }^{81}$ The hearings provide an arena in which old conflicts are played out, and sometimes escalated. In view of this, the assertion that the introduction of due process procedures has caused relations between schools and parents to deteriorate must be treated with extreme caution.

\section{V \\ The Appropriateness of the Legalization Model: The Wide Context}

\section{A. Introduction}

The implementation studies discussed in part III assess the appropriateness of legalization in special education without either considering the wider context of the education system or proposing plausible alternative means to rectify the indisputable abuses of the past. Focusing exclusively on the due process procedures and identifying only the undesirable effects associated with them misses the broader institutional changes associated with the legislation, of which due process procedures form an integral component.

Passage of the EAHCA has had an enormous effect on special education. More than 230,000 children were identified and provided with education within the first two years after passage of the law, and the rate of increase is steady. ${ }^{82}$ Although appropriations are now falling below authorizations, there has been an infusion of $\$ 950$ million in federal funds over the first two years

78. See M. Budoff \& A. Orenstein, supra note 48 , at 13-14 to -15.

79. Stearns, Green \& David, supra note 48 , at 103 .

80. M. Budoff \& A. Orenstein, supra note 48, at 9-29 to -30, 14-15.

81. See id. at 8-1 to -4 ; $f$. Hassell, supra note 45; who seems to attribute the pathologies of schools districts with a large number of hearings to "excessive legal intervention".

82. Hearings on the Implementation of P.L. 94-142 Before the Subcomm. on Select Education of the House Comm. on Education and Labor, 96th Cong., 1st Sess. 297, 299 (1979). (Evidence of Edwin W. Martin, Deputy Commissioner, Bureau of Education for the Handicapped, Office of Education, Department of Health, Education and Welfare). 
of the program, increasing to over $\$ 800$ million per year in 1980 and 1981.83 While reduced substantially under the Reagan Administration, special education has proved to be less of a casualty than other social welfare programs. ${ }^{\mathbf{8 4}}$ This enormous increase in special education expenditure has not only produced cash benefits but has also augmented the prestige and attractiveness of special education as a field of endeavor. The formal procedures mandated by the EAHCA are in place, and many new programs are being developed in school districts.

Much of this change might have been achieved without reliance on a legalized policy style. Implicit in the criticisms of due process procedures is the suggestion that the policymakers were wrong in believing that the legalized model was essential to achieve their purposes, and that legalization is inappropriate in the context of education. Even if one remains skeptical about the causal links between the due process hearings and the effects attributed to them by the studies canvassed in part III, there is good reason to be concerned about the appropriateness of the due process procedures. ${ }^{85}$ It may be that some issues, including education, are not amenable to legalized treatment. ${ }^{86}$ To determine whether special education is amenable, one must study the effects of legalization by looking beyond the hearing process to the impact of legalization on the wider institutional setting.

\section{B. Legalization and Delegalization}

Although legalization is a relatively new phenomenon in education, ${ }^{87}$ it is more prevalent in public life where there are alternating periods of reliance on formal, procedural justice and informal, substantive justice. ${ }^{88}$ The civil rights movement and the War on Poverty heavily emphasized rights, lawyers, courts, and formal procedures. ${ }^{89}$ Those who studied those movements in the late 1960's and early 1970's began to doubt the extent to which substantive goals could be achieved through the legal model, especially where the poor were the intended beneficiaries. ${ }^{90}$ The mid-1970's, by contrast, saw a growing interest in delegalization, emphasizing informal methods of dispute resolu-

83. Id. at 96, 97-98, 107. (Evidence of Frederick J. Weintraub, Assistant Executive Director for Governmental Relations of the Council for Exceptional Children).

84. The cutbacks for fiscal years 1982 and 1983 amount to 29.6 percent. Children's DefENSE Fund, A Children's Defense Budget: An Analysis of the President's Budget and Children 4 (1982).

85. On the question of the use of due process procedures in the context of school discipline, see Kirp, supra, note 5, and in schools generally, see Pittenger \& Kuriloff, supra note 45, at 89-90.

86. Lon Fuller described such issues as "polycentric issues." Fuller, The Forms and Limits of Adjudication, 92 HaRv. L. REV. 353, 371 (1978).

87. See Kirp, supra note 5.

88. See Abel, supra note 7.

89. See, e.g., three articles by Reich, Midnight Welfare Searches and the Social Security Act, 72 YaLE L.J. 1347 (1963); The New Property, 73 YALE L.J. 733 (1964); Individual Rights and Social Welfare: The Emerging Legal Issues, 74 YALE L.J. 1245 (1965).

90. See Galanter, supra note 66 ; Handler, supra note 14. 
tion, arbitration, mediation, negotiation, ombudsmen, and community dispute resolution centers. ${ }^{91}$

Underlying this dynamic is the Janus-faced nature of legalization. In its positive aspect, legalization makes several promises. It is a vehicle through which individual citizens may redress the imbalance between themselves and the state or other powerful opposing interests. It provides access to individuals unable to summon the political resources needed to obtain a legislative majority in modern politics. It offers principled decisionmaking in an impartial, procedurally balanced forum. It emphasizes accountability, administrative regularity, and the reduction of arbitrariness. ${ }^{92}$ In its other face, legalization can turn into the arid formality of legalism. ${ }^{93}$ Equality before the law is too often dependent on access to resources. Legalization can also lead to the sorts of pathologies-defensiveness, delay, hostility, expense-adverted to in part III. Emphasis on accountability and reduction of arbitrariness imply a mistrust of those administering policy, which in turn may inhibit the creative exercise of professional discretion and judgment.

This duality of the legal model plays itself out in the special education area. Previously, handicapped children were excluded from school and from their share of the education dollar; those given some instruction were often poorly treated by the education system. After years of unsuccessful political efforts, the courts were called on to restructure power relationships in the education organization which had excluded the handicapped, and to legitimize their claims by declaring that they had a right to a free and appropriate public education. The embodiment of this value in the law meant that handicapped children could no longer be excluded from school and that their claims to education were legitimized. Arguments to the contrary were nullified. Legal sanctions were available to enforce the right. The argument moved beyond the question of admission to the question of the quality of education to which the handicapped are entitled.

The EAHCA does not squarely address the difficult questions of quality and substance in special education: namely, the content of the appropriate education in a particular case. The Act provides one procedure for giving effect to the right to a free appropriate public education, the IEP, and another for enforcing it, the due process hearing. Beyond specifying a minimum criterion of compliance with state educational agency standards, the legislative definition relies on the IEP to give substance to the term "appropriate." 94 This provides little guidance for those seeking to determine what is appropriate for a specific child. Undoubtedly this will be answered in part by the due process and review procedures. But the danger, from the point of view of those seeking high quality special education, is that the emphasis on process in the legislation will leave little room for substantive arguments. The

91. Nader, supra note 60 ; see also the works cited supra note 8 .

92. We owe a number of these points to a talk on legalization given by Philip Selznick to the Berkeley/Stanford Faculty Seminar on Law, Governance and Education, October 1980.

93. See supra note 11 .

94. 20 U.S.C. $\$ 1401(18)(1982)$. 
majority in the Supreme Court decision in Rowley took this view. ${ }^{95}$ They found that the Act could "not be read as imposing any particular substantive educational standard upon the States."96 Granted that no particular substantive outcome is mandated, the question of appropriateness in a particular case remains. The Rowley opinion is only slightly helpful in defining what is appropriate because, like the legislative definition, it leaves the problem to the IEP process. ${ }^{97}$

Leaving substantive determinations to a due process hearing has both the virtues and the vices of legalization. It contemplates principled arguments about the amount and type of services due to a given child. This may be preferable to such alternatives as centralized bureaucratic decisionmaking, with its attendant problems of distance and rigid categorizations, or professional judgments, often paternalistic and highly deferential to the needs of the professionals at the expense of the handicapped student. On the other hand, it leaves open the possibility of legalism: that is, strict compliance with procedures as a means of avoiding review of the substance. ${ }^{98}$

The legalized model creates other problems as well.99 Handicapped children are accorded formal rights not made available to other children in the education system. There is, for instance, a tendency for rights to know no dollar limitations. ${ }^{100}$ Yet the reality that school administrators face is that they have limited budgets and must make difficult decisions about the just distribution of those funds among competing sectors of the school system.

Ambiguity surrounding the word "appropriate" also produces tension between schools and parents. School officials complain about parents looting the public treasury to obtain private school placements and express frustration that they feel unable to put these sorts of arguments to the hearings officers. The officials' inability to use these arguments may be attributable to the tendency of due process hearings to individualize problems, but it is not a necessary interpretation of the legislation. Acting on this perception, school administrators are resorting to indirect means of protecting funds, adopting defensive or delaying tactics, and attempting to translate arguments based on the needs of the school system in general into arguments about a particular child. For their part, parents' expectations may have been raised to unrealistic levels by the law. Their concern is likely to reside exclusively with their own child; in their eyes the word "appropriate" may have come to mean whatever is appropriate regardless of the cost. This would explain parents' frustration with school districts and their perception of a lack of candor in the school officials with whom they deal.101

The effect of the EAHCA is to segment decisionmaking. power, empow-

95. Board of Educ. v. Rowley, 458 U.S. 176 (1982).

96. Id. at 200 .

97. Id. at 203.

98. The majority in Rowley seemed to envisage something approaching this position. Id. at 205.

99. See generally Fuller, supra note 86 .

100. Mills v. Board of Educ., 348 F. Supp. 866 (D.D.C. 1972).

101. M. Budoff \& A. Orenstein, supra note 48, at 9-14 to -24, 13-10; Stearns, Green \& David, 
ering hearing officers from outside the school administration to make decisions about potentially large slices of the school's budget. It is not clear whether the hearing officer is supposed to take into account the budgetary realities of the school system as a whole, of the special education segment of that system, or just of the educational merits of the program proposed for a particular child.

While this dispute over the relevance of costs is partly attributable to the fact that entitlements of handicapped children, but not those of nonhandicapped children, are clearly spelled out, it is also partly a function of the adjudicative process. The hearing mechanism is, in its ideal form, a case-by-case process. It formally assumes that two parties are disputing in a contextual vacuum. That fiction alone is enough to give rise to considerable frustrations. Moreover, different hearing officers will render different decisions on similar cases. There is no consistent interpretation of "appropriate," and there does not appear to be much communication among hearing officers about their decisions. ${ }^{102}$ While this may change as precedents develop, several factorsthe variegated nature of appropriateness, the fact that hearing officers lack either the legal or educational expertise to render consistent judgments, and the variability of schools and handicapping conditions-make consistency unlikely.

Modest changes in the law would improve the situation. For one, the legislation should be amended to make it clear that arguments based on the overall needs of the school system (subject to proof and open to challenge in the hearing) are germane to the question of appropriateness. ${ }^{103}$ Use of informal dispute resolution techniques seems to be producing good results and should be encouraged. ${ }^{104}$ Greater information, attention to problems at an early stage, and the use of mediation prevent the escalation of conflict in a significant number of cases. ${ }^{105}$

The broadest concerns relate to the effects of legalization of special education on the school as a bureaucratic/professional organization. ${ }^{106}$ Schools face serious problems of coordination, confronting acutely complex questions of distributive justice among different elements of their program, of management vis-a-vis their own professional staff, and of accountability to the community, especially to the parents of currently enrolled students. The meaning

supra note 48 , at $108 \& 113$; see also Kirst \& Bertken on the potential for distorting funds, supra note 48.

102. M. Budoff \& A. Orenstein, supra note 48, at 13-24; Stearns, Green \& David, supra note 48, at $107-08$.

103. A recent case maintained that, in view of P.L. 94-142, the 180-day limitation on the school year could not be maintained for seriously handicapped children. This may imply a very broad interpretation of "appropriate" which would exacerbate the potential for distortion of school finances. Armstrong v. Kline, 476 F. Supp. 583 (E.D. Pa. 1979), remanded sub nom. Battle v. Pennsylvania, 629 F.2d 269 (3d Cir. 1980), cert. denied, 452 U.S. 968 (1981). But cf. Rowley, 458 U.S. 176 (1982) (Supreme Court chose relatively narrow interpretation of appropriate).

104. M. Budoff \& A. Orenstein, supra note 48, at ch. 12; Stearns, Green \& David, supra note 48.

105. M. Budoff \& A. Orenstein, supra note 104.

106. See the discussion of law in the context of discrimination in L. Mayhew, supra note 6 . 
of a good education is controversial, and limited in any case by funding realities. Potential lines of conflict run in every direction: between school board and principal, school board and teachers, teachers and principal, teacher and student, and teacher and parents.

The effect of legalization on special education entails a radical reorientation of this complex network. It empowers what was previously an out group; the handicapped must now be included in policy decisions. No one in the school system can maintain that handicapped children should be excluded from school, at least not publicly. The force of the state and the moral authority of the law is available to the handicapped. In arguments over services and resources the claimants can point to their legal entitlement to rebut the arguments of their opponents. The IEP has the force of law, and parents and special education teachers can use this to press their claims on behalf of handicapped children. Parents of the handicapped can also look to the law rather than to the generosity of the school system to define their entitlement. In short, the EAHCA effects a shift in bargaining power and prevents the claims of the handicapped from being fobbed off. As has been said in the context of anti-discrimination laws: "We like to use reason, not force. It isn't right to talk reason out of one side of your mouth and law out of the other, but before the law was passed they weren't as willing to listen to reason." 107

Legalization has also improved the status of the special education professional. In an era of shrinking education budgets, special education has received an infusion of new money. It has become an attractive area for new teachers and a way for existing teachers to earn additional salary and avoid retrenchment. Special education teachers are assuming places in school administration that they had not held earlier. This development too will affect the organizational goals of schools and strengthen the perceived legitimacy of the claims of the handicapped.

The pathologies of legalization must also be acknowledged. There is some evidence that the values promoted by the legislation are provoking resistance from the education community. Despite increased funding, there are too few resources to treat all handicapped children individually. ${ }^{108}$ By distinguishing the handicapped children from the regular school network and granting them rights not enjoyed by other school children, the law potentially distorts the allocation of resources. This potential is aggravated by the legal model which treats the parties to a dispute as discrete from the system in which they are located.

Further, legalization betrays a mistrust of schools. It may inhibit the discretion of professionals ${ }^{109}$ whose judgment should be exercised creatively on

107. Id. at 275 .

108. R. Weatherley, supra note 47, at 73, 141-50 (pointing out the tensions involved in requiring bureaucracies to treat their clientele as individuals).

109. We are not alone in saying that the situation is poised to go either way. See Schlechty \& Turnbull, Bureaucracy or Professionalism: Implications of P.L. 94-142, 29 J. TCHR. Educ., Nov.-Dec. 1978, at 34 . 
behalf of the child. ${ }^{110}$ In the past that distrust may have been deserved. But legalization can be a blunt instrument, undermining healthy as well as malevolent exercise of discretion. Special education teachers now find themselves as "defendants" in due process hearings. This represents a marked change from their self-perception, prior to passage of the EAHCA, as lone advocates for the handicapped child. From the viewpoint of the handicapped it would be disastrous to alienate this group, particularly in view of their role as primary service providers and their new status in the school hierarchy. Encouraging mediation and negotiation, rather than due process hearings, should diminish this danger. Moreover, resolution of the appropriateness issue should release special educators from the somewhat false position in which they currently find themselves having covertly to argue on behalf of the needs of the school system. Once recognized as legitimate, the system's needs could be advanced openly by representatives of the wider interests, leaving special educators to put the case for their component of the system. Parents would be less likely to maintain unreal expectations. In this way, parents and teachers could be reunited in the task of providing the best education, within budget constraints, for handicapped children.

Finally, the utility of the due process hearing as a compliance device is dubious. Individualization, lack of coordination, and the settlement of strategic cases to avoid hearings suggest systemic problems which may be missed by the individualized nature of the hearings. Hearings alone are ill-suited for the task of precipitating systemic review and reform. ${ }^{111}$ Agency-wide review, litigation, and political change remain key parts of appraising and modifying any program.

Only in the context of those wider considerations may the appropriateness of legalization be assessed. Legalization jolted the education system into according handicapped children a fair share of the education pie. As the system comes to accept the presence of handicapped children and recognizes the legitimacy of their claims, and as special education teachers acquire new status in school hierarchies, there are sound reasons to diminish reliance on some aspects of the legalized structure of special education.

110. On the subject of growing government intervention in the classroom, see the following: In such a climate the teacher might be forgiven if he or she feels whipsawed, disaffected and even resentful. Teachers, I think, have been highly desirous of responding to educational concerns featured in the mass media, and they see themselves as having tried earnestly and sometimes valiantly to meet the objectives that seem important at any given time for the schools; but they become confused and angry because of the rapid change in educational priorities their resistance to external influence stiffened. I believe that this resistance to external influence, however beneficial that influence potentially may be, has been one unanticipated result of government activity in the curriculum field.

Atkin, supra note 45 , at 96 .

111. See Mashaw, The Management Side of Due Process: Some Theoretical and Litigation Notes on the Assurance of Accuracy, Faimess and Timeliness in the Adjudication of Social Welfare Claims, 59 CORNELL L. REv. 772 (1974). 


\section{Conclusion}

Development of special education policy occurred during the heyday of legalization, but the continued prominence of legalization as a policymaking style seems less likely. The force of the civil rights era, which gave so much impetus to the development of the special education policy, is spent. The rhetoric of rights has waned as calls for smaller government, lower taxes, and budget cuts produce a climate skeptical of new claims on the public sector and doubtful about many of the old ones. These rights may themselves be trimmed back by budget cuts, legislative repeal, and judicial circumspection.

This is not to suggest, however, that legalization will disappear from public life, for the values it symbolizes are too deeply embedded in the political culture. Oscillation between legalization and delegalization, reflecting the tension between procedural and substantive justice, is the likely pattern for the future. The lessons to be learned from the special education history speak to individuals' rights to enjoy essential public services and to participate in decisions affecting delivery of those services. These values remain fundamental in American public life. Yet there are also lessons to be learned about the impact of law on complex organizations and the balancing of all interests within those organizations.

Legalization is a powerful tool which needs to be understood and used with sensitivity. In the long run, there can be no easy solution to the difficult questions of distribution in organizations with conflicting interests competing for limited funds. Outright exclusion, such as handicapped children suffered, is no answer; neither is the enfranchisement of one group with little effort to relate that group's needs to those of other claimants. Those who would undertake the legalization of a policy area must take careful account of the context into which the policy is introduced, for only in this way can the appropriateness of legalization be weighed against alternative policy courses. 
